Matthew C. Hunter

Liquid Intelligence Introduction

\title{
Curve, Line, CirCle, Slash, Cross: A Diagram OF LiQuid INTELligenCE
}

In the opening line of his four-paragraph essay "Photography and Liquid Intelligence” (1989), photographer Jeff Wall directs the reader’s attention to Milk, his lightbox-illuminated Cibachrome transparency of 1984. (Fig. 1: Milk) A study in planarity, Milk poses a man crouching at street level before an architecture of bricked mensuration. The figure grasps a carton of milk concealed in a paper bag. His forearm is taut, jaw clenched; an outstretched, sockless shoe is stripped of laces. From the container's unfolded spout, white liquid spurts upwards to describe a half arc of interrupted, curving form against the bricks' relentless geometry.

What has caused this explosion? The grasping hand holding the carton gives no sign of the compression required to create the spray, nor does the figure's right arm betray evidence of motion. For Wall, the image's inexplicable action becomes part of an allegory for photography itself. By that account, the “dry,” optical spaces of the photographic camera and enlarger exemplify a familiar, modern visuality: a "technological intelligence of image-making, with the projectile or ballistic nature of vision when it is augmented and intensified by glass (lenses) and machinery (calibrators and shutters).”1 But, registering in Milk's furling flows are the darkroom's shadowy pools of fixatives and washes required for chemical photography’s visual activation. "I think of this sometimes," Wall puts it, “as a confrontation of what you might call the 'liquid intelligence' of nature with the glassed-in and relatively 'dry' character of the institution of photography."2 Where the stasis of Milk's tectonic planes is activated by fluid eruption, so photography in this telling emerges as the dialectical yield between two opposing modes of intelligence: dry and liquid, modern and ancient, knowing and unknowable.

\footnotetext{
${ }^{1}$ Jeff Wall, "Photography and Liquid Intelligence," in Jeff Wall, eds. T. de Duve et al. (London: Phaidon, 1996), 90.

${ }^{2}$ Wall, 90.
} 
A dry, ballistic intelligence of technological modernity might seem abundantly familiar to readers of Grey Room. What of "liquid intelligence”? Contemporary prompts for sounding it are found easily enough. Before any talk of drip or pour paintings, liquid word pictures, the abject viscosities of the informe or other art-world stalwarts, the phrase could call to mind the "liquid modernity" used to denote our deracinated, deregulated era. ${ }^{3}$ The melting of solids prophesized by Marx and Engels has been held in suspension, by Zygmunt Bauman’s analysis, for the exercise of “increasingly mobile, slippery, shifty, evasive and fugitive power." ${ }^{4}$ Mobilizing the digital age’s ubiquitous palette of the liquid crystal display, some technophilic campaigners have called for a "liquid democracy" that would replace representational politics with referendum-based interventions. ${ }^{5}$ If various forms of fluidity and plasticity could be traced through the choppy currents of post-Lacanian feminism, deconstruction and cognitive neuroscience, then the rising sea levels, melting ice caps and desolation of the oceans’ biosystems-environmental catastrophes signaled too in Wall's pithy essay—will soon make practical recourse to liquid intelligence matters of urgent necessity. ${ }^{6}$

Yet, Wall's essay also opens away from the present. An "archaism of water, of liquid chemicals," liquid intelligence:

connects photography to the past, to time, in an important way. By calling water an 'archaism' here I mean that it embodies a memory-trace of very ancient production processes — of washing, bleaching, dissolving and so on, which are connected to the origin of technè-like the separation of ores in primitive mining, for example. I think that this 'prehistorical' image of photography-a speculative image in which the apparatus itself can be thought of as not yet having emerged from the mineral and vegetable worlds — can help us to understand the 'dry' part of photography differently. ${ }^{7}$

\footnotetext{
${ }^{3}$ See, for example, Yve-Alain Bois, Edward Ruscha: Romance with Liquid, Paintings 1966-1969 (New York: Gagosian Gallery/Rizzoli, 1993); Allan Sekula, "Between the Net and the Deep Blue Sea (rethinking the Traffic in Photographs)," October 102 (Autumn 2002): 3-34; and Kenneth Hayes, Milk and Melancholy (Toronto: Prefix Press, 2008).

${ }^{4}$ Zygmont Bauman, Liquid Modernity (Malden: Polity Press, 2000), 14.

${ }^{5}$ See Esther Leslie, Liquid Crystals: The Art and Science of a Fluid Form (London: Reaktion, 2017); http://liquidfeedback.org/ [accessed Oct. 31, 2016].

${ }^{6}$ Compare Luce Irigaray, “The 'Mechanics' of Fluids,” in This Sex Which is Not One [1977], trans. Catherine Porter with Carolyn Burke (Ithaca: Cornell University Press, 1985), 106-118; Catherine Malabou, Plasticity at the Dusk of Writing: Dialectic, Destruction, Deconstruction [2005], trans. Carolyn Shread (New York: Columbia University Press, 2010).

${ }^{7}$ Wall, 90.
} 
What would it mean to imagine a broader genealogy of liquid intelligence informed by the expansive technical history Wall evokes? While Wall has hardly been alone in exploring alternate prehistories of photography, looking with an eye attuned to the matter compels us to see ways in which an unconscious sounding of liquid intelligence is already afoot in recent histories of the arts and architecture of an expanded early modernity. ${ }^{8}$

Guided by the interdisciplinary currents of the "new thallasography,” such an inquiry would logically gather at the greater confluence of the Mediterranean and Black Seas in the fabric of Hagia Sophia—its architecture acting as a giant acoustic resonator to meld human voices into an oceanic murmur; its book-matched marble pavements simulating a vast expanse of water as a "horizon on which human finitude is set between lucid firmness and umbrous chaos.”9 Yet, outward from Milk's curving streams, a tale could equally be told in diagrammatic terms, moving first from line to circle. ${ }^{10}$ After all, the edifice of northern Renaissance image-theology was built, by Joseph Koerner's reading, on the backs of unctuous figures: miraculous pictures dragged off the surface of ponds or the sudarium (sweat cloth) pulled from the face of Christ by St. Veronica in the contact relic that would take her name. ${ }^{11}$ Found not fabricated; made without the intervention of human hand, the moist imprint of Christ's face gave theological sanction to figural depiction in an era increasingly suspicious of "graven images.” And working in the medium of oil paint that Jan van Eyck (1390-1441) had mythically invented as he turned from the sun that ruptured his drying pictures toward the darkened, controllable spaces of "alchemy and

\footnotetext{
${ }^{8}$ For apposite photo-historical interventions in the pages of this journal, see Patrick R. Crowley, "Roman Death Masks and the Metaphorics of the Negative," Grey Room 64 (2016): 64-103; and Peter Geimer, "A Self-Portrait of Christ or the White Noise of Photography? Paul Vignon and the Earliest Photograph of the Shroud of Turin," Grey Room 59 (2015): 6-43. More broadly, see Kaja Silverman, The Miracle of Analogy, Or, the History of Photography (Stanford: Stanford University Press, 2015); Photography and Its Origins, eds. Tanya Sheehan and Andrés M.

Zervigón (New York: Routledge, 2015); and RES 63/64, Special Issue: Wet/Dry, ed. Christopher S. Wood (Spring/Autumn 2013): 1-347.

${ }^{9}$ See, respectively, Peregrine Horden and Nicholas Purcell, The Corrupting Sea: A Study of Mediterranean History (Oxford: Blackwell, 2000); The Sea: Thalassography and Historiography, ed. Peter N. Miller (Ann Arbor:

University of Michigan Press, 2013); Bissera V. Pentcheva, "Hagia Sophia and Multisensory Aesthetics," Gesta 50, 2 (2011): 93-111; and Fabio Barry, "Walking on Water: Cosmic Floors in Antiquity and the Middle Ages," The Art Bulletin 89, 4 (2014): 627-656.

${ }^{10}$ For a rich treatment, see Eric de Bruyn, "Beyond the Line, or a Political Geometry of Contemporary Art," Grey Room 57 (2014): 24-49.

${ }^{11}$ See Joseph Leo Koerner, The Moment of Self-Portraiture in German Renaissance Art (Chicago: University of Chicago Press, 1993), 81.
} 
distillation” (Alchemie en Distillatien), Albrecht Dürer (1471-1528) audaciously replaced the sudarium’s holy face with his own visage - the human face of a Christ-like painter. ${ }^{12}$ Koerner traces this line as a volte-face, “a kind of Copernican revolution of the image.”13

Fluids brought into line by a virtuosic self would thus move away from Foucault’s orders of similitude to draw the bounds of Renaissance intelligence anew. ${ }^{14}$ In Michael Cole’s revisionary work, Benvenuto Cellini (1500-1571) is neither the paragon of Jakob Burckhardt's uomo universale nor was his training as a goldsmith but some perfunctory prolegomenon for entry into Giorgio Vasari’s arts of disegno. (Fig. 2: Perseus) Instead, Cellini’s command of the technics and poetics of poured, molten metals amounts to a "goldsmith’s intelligence," which ensnares rivals working in subtractive media while elevating the art of cast bronze. ${ }^{15}$ By scriptural tradition, the casting of metals had been redolent with a specious animism materialized in nothing less than the Ur-idol of the Golden Calf. " 'I threw it into the fire, and out came this calf!'” (Exodus 32:24); so Aaron protests to Moses after gathering and liquefying the Israelites’ golden jewelry. By contrast, Cole’s Cellini moves with the “artisanal epistemology” through which command over materials earned by bodily blood, sweat and tears came to rival textual learning as a legitimate source of natural knowledge. ${ }^{16}$ Arrogating from God the capacity to create and not simply replicate nature's forms, this tradition could figure the artist’s brain as "a moist organ, in which

\footnotetext{
${ }^{12}$ See Karel van Mander, The Lives of the Illustrious Netherlandish and the German Painters [1603-4], trans. and ed. H. Miedema (Doornspijk: Davaco, 1994), 56-7.

${ }^{13}$ Koerner, 122.

${ }^{14}$ See Michel Foucault, Les mots et les choses: Une archéologie des sciences humaines (Paris: Gallimard, 1966), 32-59.

${ }^{15}$ Compare Michael Cole, Cellini and the Principles of Sculpture (New York: Cambridge University Press, 2002), 8-9, 15-17; and idem, “Cellini’s Blood,” The Art Bulletin 81, 2 (1999): 215-235.

${ }^{16}$ Pamela H. Smith, The Body of the Artisan: Art and Experience in the Scientific Revolution (Chicago: University of Chicago Press, 2004).
} 
the movement of fluids propelled the creation of thoughts and the recollection of memories." ${ }^{\text {17 }}$ Such brawny intelligence would find its organizing theme in what Cole calls "the control of liquids.”18

Channeling flow into line also means parsing-policing—liquid intelligence from deluding, deceiving waters. (Fig. 3: Narcissus) Faced with the challenge of Caravaggio’s so-called naturalism and the serial replication augured by the printing press, Richard Neer argues, Nicolas Poussin (1594-1665) looked to fluids. With their watery pools dumbly doubling figure and sky, Poussin’s mythological landscapes stage the immanent danger: "Just as mechanical reproduction is the 'sepulchre' of painting, just as pictorial realism turns artists into animals, so ... the sterile mimicry of Narcissus and Echo results both in the loss of both life and humanity." ${ }^{19}$ Consigned to the narcissistic order of death Poussin famously calls “aspect”, watery reflection stands in counterpoint to the reasoned order of "prospect” and a generative, emulative mode of allegorical imitation that the painter figures around the rebirth of the winegod Bacchus in a moist grotto. In Paradise Lost (1667), Milton’s Eve first wakes to gaze upon Eden’s waters: "Smooth lake, that to me seemed another sky." Staring down into that fluid world, she sees "a shape within the wat'ry gleam ... with answering looks / Of sympathy and love." ${ }^{20}$ Like Poussin, Milton’s Adam seeks to break liquids' specular spell, identifying "that smooth wat'ry image” with Eve herself and contrasting it to a fluid order he will install. "Follow me,” Adam charges, and “... thou shalt bear / Multitudes like thyself, and thence be called / Mother of the human race."21 Inseparable from the pretensions of a hereditary nobility, a parsed, purified line of genealogical descent distinguished from the

\footnotetext{
${ }^{17}$ Marissa Anne Bass, "The Hydraulics of Imagination: Fantastical Fountains in the Drawing Books of Jacopo Bellini,” in Imagination und Repräesentation: Zwei Bildsphären der Frühen Neuzeit, eds. Horst Bredekamp et al. (Munich: Wilhelm Fink, 2010), 156. Compare Erwin Panofsky, “Artist, Scientist, Genius: Notes on the Renaissance-Dämmerung," in The Renaissance: Six Essays, eds. W. K. Ferguson et al. (New York: Harper \& Row, 1962), 121-182; and William R. Newman, Promethean Ambitions: Alchemy and the Quest to Perfect Nature (Chicago: University of Chicago Press, 2004).

${ }^{18}$ Cole, Cellini, 39.

${ }^{19}$ Richard T. Neer, "Poussin, Titian, and Tradition: The Birth of Bacchus and the Genealogy of Images," Word \& Image 18, 3 (2002): 275.

${ }^{20}$ John Milton, Paradise Lost [1667], in John Milton: The Complete Poems, ed. J. Leonard (New York: Penguin, 1998), Book IV:

${ }^{21}$ Milton, IV: 473-475.
} 
deluding, diluted pool would reach an apex in the rituals of Absolutist state-craft. ${ }^{22}$ From the octagonal space of his grande laiterie within Versailles’s 1660s menagerie, Meredith Martin argues, Louis XIV poured milk and offered dairy consumables to a politically gelded nobility. Attesting to the purity of the Bourbon blood-line and his own fructifying force, Louis’s performances claimed “women and gardens as raw materials for his own (male) production. The grande laiterie took up where these female allegories left off, as a womblike space that he could utilize to transform the red blood of war into the white milk of peace."23

But, a liquid intelligence in seventeenth-century conception could not bend only to linear circumscription. Anatomizing an Ark of serpents, frogs, snails, dogs and pigs, royal physician William Harvey (1578-1657) pursued the motion of the heart's ventricles to a new geometry of blood, “a movement, as it were, in a circle.”24 Frédéric Cousinié has recently evoked "a general economy of fluids characterized by mobility, convertibility, and reciprocal exchange” as defining preoccupations of French painting in the early seventeenth century. ${ }^{25}$ In that age of fen-draining and corporate water supplying, such circulatory models might equally be seen as paradigmatic to the political anatomy of intelligence. ${ }^{26}$ (Fig. 4: Willis) Oxford-based physiologist Thomas Willis (father of our "neurocentric age,” as one writer has put it) excavated the eponymous, cerebral "Circle of Willis" to disclose a fluid infrastructure of thought's pulsing movement. ${ }^{27}$ With "the Fountains of the Primary Spirits ... placed in the top it self of the Body,” Willis argues with terms taken from alchemical instrumentation, the brain distills animal spirits off from the blood, which then cascades down through the corporeal frame "as it were by Bills and

\footnotetext{
${ }^{22}$ See Wolfram Schmidgen, Exquisite Mixture: The Virtues of Impurity in Early Modern England (Philadelphia: University of Pennsylvania Press, 2013).

${ }^{23}$ Meredith Martin, Dairy Queens: The Politics of Pastoral Architecture from Catherine de' Medici to MarieAntoinette (Cambridge: Harvard University Press, 2011), 86.

${ }^{24}$ William Harvey, The Circulation of the Blood and Other Writings, trans. Kenneth J. Franklin, intro. Andrew Wear (London: J.M. Dent, 1990), 46.

${ }^{25}$ Frédéric Cousinié, Esthétique Des Fluides: Sang, Sperme, Merde Dans La Peinture Française Du Xviie Siècle. (Paris: Félin, 2011), 16.

${ }^{26}$ See Frances Willmoth, "Surveying the Fens," Sir Jonas Moore: Practical Mathematics and Restoration Science (Rochester: Boydell Press, 1993), 88-120; Leslie Tomory, "London’s Water Supply Before 1800 and the Roots of the Networked City,” Technology and Culture 56, 3 (2015): 704-737.

${ }^{27}$ See Carl Zimmer, Soul Made Flesh: The Discovery of the Brain—and How It Changed the World (New York: Free Press, 2004), 7.
} 
Pelicans placed here and there, into all the inferiour parts” to be cycled back up again. ${ }^{28}$ For Willis’s understudy Robert Hooke (1635-1703), that circulatory pattern was as much social as it was physiological. True philosophy, Hooke claims, "is to begin with the Hands and Eyes, and to proceed on through the Memory, to be continued by the Reason; nor is it to stop there, but to come about to the Hands and Eyes again, and so, by a continual passage round from one Faculty to another, it is to be maintained in life and strength, as much as the body of man is by the circulation of the blood."29 Knowledge could not simply be handed down in a vertical line from professor to student; it could only grow in vitality as it circled between capacities and social stations. ${ }^{30}$

Nowhere would that force of the circle and its movement beyond the order of the line become more ubiquitous than in long-eighteenth-century conversations about political economy. Literary historian James Thompson identifies a crucial double movement in the period's conception of money: shifts from bullion value weighed to nominal value read and from stable treasure to be horded to capital increased by movement. ${ }^{31}$ For Thompson, the campaign of philosopher John Locke to restore England's corrupted coinage to its Elizabethan weight values exemplifies a materialist, conservative "law of continuity: that material substance is the same from moment to moment. ... [which] is, of course, the most cherished principle of landed aristocracy—-that the paternal estate is bounded by the same hedgerows through the centuries.”32 By contrast, the nominalist, capitalist vision consolidating through the eighteenth century figures circulating currency as means for nourishing economic growth as a river does parched earth. ${ }^{33}$ From a grounding in land to the fluids that replenish it, money in Adam Smith’s An Inquiry into the Nature and Causes of the Wealth of Nations (1776) is "a sort of waggon-way through the air; ...

\footnotetext{
${ }^{28}$ Thomas Willis, Two Discourses Concerning the Soul of Brutes, trans. Samuel Pordage (London: Thomas Dring, 1683), 23.

${ }^{29}$ Robert Hooke, Micrographia, Or, Some Physiological Descriptions of Minute Bodies Made by Magnifying Glasses (London: Printed by Jo. Martyn and Ja. Allestry, 1665), sig. b iii.

${ }^{30}$ See Matthew C. Hunter, Wicked Intelligence: Visual Art and the Science of Experiment in Restoration London (Chicago: University of Chicago Press, 2013).

${ }^{31}$ James Thompson, Models of Value: Eighteenth-Century Political Economy and the Novel (Durham: Duke UP, 1996), esp. 43-4.

${ }^{32}$ Thompson, 60.

33 Thompson, 71, 75.
} 
[enabling] the country to convert, as it were, a great part of its highways into good pastures and cornfields, and thereby to increase very considerably the annual produce of its land and labour.”34

In the hands of Svetlana Alpers and Michael Baxandall, that positive potential for fructifying, circulatory movement becomes crucial to eighteenth-century “pictorial intelligence.” Interpreting Venetian painter Giovanni Battista Tiepolo (1696-1770), Alpers and Baxandall argue for a fluid aesthetics of lightness and mobility at the center of his project. ${ }^{35}$ Watching the "freakish intermittent effect" of moving water reflecting off the ceiling designs Tiepolo painted quickly into wet plaster intonaco, the authors find pictorial programs built in collaboration with, not suppression of, complex interplays of light bouncing off the surfaces of Venice’s canals. ${ }^{36}$ Where Tiepolo’s pictorial intelligence "postulates a mobile light and ... and a mobile viewer,” it positively chafes under constraints to its freedom: inert illumination from infelicitous architecture or "paralysing” quadratura frames that variously "straightjacketed" and "locked” its "fluid potentiality." ${ }^{37}$ Whether or not Tiepolo and his patrons could have subscribed to the tenets of Smith's political economy, intelligent handling of the Enlightenment painter's art had, by this account, come to entail negotiation with circulating patterns and the "free," value-adding contribution of the beholder they implied.

By the lights of recent scholarship, then, it is not sufficient to say that eighteenth-century liquid intelligence modeled the beholder as a ship sailing under some "blue-water" policy. ${ }^{38}$ For, the work of an artists such as John Singleton Copley (1738-1815) shows how profoundly the venerable analogy of the painting-as-ship was then sounded when contemplating pictorial ontology itself. ${ }^{39}$ By Jennifer L. Roberts’s reading, Copley “spent the first ten years of his life in his mother's tobacco shop on Long Wharf, an immense pier jutting ... a quarter of a mile into the center of Boston Harbor. Copley would

${ }^{34}$ Adam Smith, An Inquiry into the Nature and Causes of the Wealth of Nations (Dublin: Whitestone et al., 1776), Vol. II: 73.

${ }^{35}$ Svetlana Alpers and Michael Baxandall, Tiepolo and the Pictorial Intelligence (New Haven: Yale University Press, 1994), 51-3; 58.

${ }^{36}$ Alpers and Baxandall, 84-88.

${ }^{37}$ Alpers and Baxandall, 97; 94.

${ }^{38}$ See Daniel A. Baugh, “Great Britain’s ‘Blue-Water’ Policy, 1689-1815,” The International History Review 10, 1 (February 1988): 33-58.

39 Jennifer L. Roberts, Transporting Visions: The Movement of Images in Early America (Berkeley: University of California Press, 2014), 16. 
have awakened each morning to a noisy, smelly, colorful panorama of merchant shipping activity." 40 That embodied, multi-sensorial nous provides Copley with the logistical capacity to ship his Boy with a Flying Squirrel across the Atlantic to unknown exhibitors in London; but, Copley’s understanding of the precarious nature of the attempted oceanic relay pervades the exported picture's iconographic program and visual form. Nonetheless, Copley’s “parcellated, modularized, dehydrated, pickled, or pressed” pictures modeled on the age of sail would soon be usurped by an intelligence calibrated not to water's liquid form, but to its gaseous state: to steam. ${ }^{41}$ (Fig. 5: Turner) This is the story Michel Serres tells around Joseph Mallard William Turner (1775-1851), "the first real genius of thermodynamics." ${ }^{22}$ Serres opposes Turner's obsessions with "the furnace, the water, the hot and the cold, matter in fusion" to the classical-mechanical world of applied geometries essential to wind-borne sailing ship’s calculations. ${ }^{43}$ Where contemporary painter of the apocalyptic landscape John Martin would envision engineering schemes to recycle the Thames’ sewage into agricultural fertilizer, Turner turns liquid intelligence into the terms of a different physics: "perception on a stochastic basis has replaced the drawing of form." 44

This sense of an altered regime between the eighteenth century and the era augured by thermodynamics is palpable in the work of Michael Fried for whom liquid intelligence has been an acknowledged object of reflection. ${ }^{45}$ In the early decades of the eighteenth century, quiet scenes of concentrated attention on the everyday—scenes of "absorption” (a term not without fluid resonance)—as rendered by Jean-Baptiste-Siméon Chardin (1699-1700) had spoken of what Fried calls “not ... time wasted but of time filled (as a glass may be filled not just to the level of the rim but slightly above).”46 The crisis of that absorptive tradition by the middle decades of the nineteenth century would be epitomized by the strange uses made of liquids in the art of Gustave Courbet (1819-1877). In Courbet,

\footnotetext{
40 Roberts, 20.

41 Roberts, 46.

${ }^{42}$ Michel Serres, “Turner Translates Carnot,” in Calligram: Essays in New Art History from France, ed. N. Bryson (New York: Cambridge University Press, 1988), 158.

43 Serres, 160.

44 Serres, 160. See Lars Kokkonen, “The Prophet Motive? John Martin as a Civil Engineer,” in John Martin: Apocalypse, ed. Martin Myrone (London: Tate Publishing, 2011), 35-41.

45 See Michael Fried, “Jeff Wall, Wittgenstein and the Everyday,” Critical Inquiry 33, 3 (Spring 2007): $495-526$.

${ }^{46}$ Michael Fried, Absorption and Theatricality: Painter and Beholder in the Age of Diderot (Los Angeles:

University of California Press, 1980), 51.
} 
water figures "as a natural metaphor of continuity, of the spilling-over of the contents of the painting into the world of the beholder, and therefore of the incapacity or the refusal of the painting to confine its representation (to confine itself) within hard-and-fast limits. ${ }^{\text {47 }}$ Welling, streaming, pooling into the nether regions of his portraits and landscapes, Courbet's waters render his canvases just as inscrutable as the "boggy, soggy, squitchy picture” that vexes Ishmael at Melville’s Spouter-Inn. ${ }^{48}$ "The bottom edges of his paintings," as Fried puts it, "have a problematic status unlike anything to be found in the work of any painter before or since.”49 The proposition here is that Courbet could neither simply ignore the beholder before the painting nor deploy tactics of dramatic action to sustain the fiction of the picture's selfenclosure, thereby nullifying the force of a beholder's presence. Where Chardin achieved absorption by rendering liquids in their brimming fullness, Courbet musters flows that move by serpentine paths to carve out those soggy pictorial bottoms while figuring a flood of reciprocal movement into the painted world. ${ }^{50}$ An ingenious solution to absorption's crisis, Courbet’s circulating, colliding fluids ford what Fried labels "the ontological impermeability of the picture surface, by which I mean its standing as an imaginary boundary between the world of the painting and that of the beholder." ${ }^{\text {51 }}$ Liquidating the bottom edge and surging in, Courbet realizes himself not before his pictures, but inside them. Overstepping the line, the circle is again closed.

\section{SLASH, Cross}

Friedian sanction alone may be sufficient to sink, scupper or slash liquid intelligence from the concerns of some Grey Room readers. Those are not the only grounds for skepticism. In 1964, Britishborn psychologist Raymond Cattell (1905-1998) added to a mountain of research contributions—some fifty books, five hundred journal articles, dozens of testing protocols—-with an enduring bifurcation in the analysis of human intelligence. Cattell parsed general intelligence $(g)$ into what he called "fluid" and

\footnotetext{
${ }^{47}$ Michael Fried, Courbet's Realism (Chicago: University of Chicago Press, 1990), 59

${ }^{48}$ Herman Melville, Moby-Dick: or, The Whale [1851] (New York: Quality Paperback Book Club, 1996$), 10$.

${ }^{49}$ Fried, Courbet's Realism, 59.

${ }^{50}$ Compare Fried, Courbet's Realism, 120-125, 131-2; 209-215.

${ }^{51}$ Fried, Courbet's Realism, 59.
} 
“crystallized” intelligence (or gf and gc, respectively). By this account, fluid intelligence is expressed most clearly in situations demanding improvisation and adaptation where skills learned by habit are of little avail. Cattell puts it this way:

For any same-age group the nature-nurture variance ratio will be much higher for gf than gc on the hypothesis that gf is directly physiologically determined whereas gc is a product of environmentally varying, experientially determined investments of gc. ... However, although it is our hypothesis that gf is biologically and physiologically determined, as a function of total cortical cell count, this does not mean that one would expect anything like complete hereditary determination. For environment includes gestation period influences and later physical trauma and physiological change, all affecting gf. ${ }^{52}$

Speaking to Cattell's larger contribution to multi-variant factor analysis in the study of human personality, this bifurcation has had profound influence. “A landmark contribution, cited not only in every book on intelligence but also in numerous introductory psychology books,” one recent interpreter notes, “the separation of fluid and crystallized intelligence has been one of Cattell's most enduring substantive contributions of psychology."53

Multiple variants aside, heredity plays a forceful role in Cattell's thinking. Not only is the fluid more nimble than crystallized intelligence in his scheme, but it also abides where crystallized, book learning decays and is, in a sense, always already dead: "If the crystallized abilities are, as it were, a dead coral formation revealing by its outlines the limits of growth of the original living tissue, the crystallized abilities will approximately the same intercorrelations as the original fluid abilities." 54 In fact, when correlating tabulated data of gf and gc, Cattell declines the possibility that these two modes of intelligence combine in some new form. Instead, they need to be read through "a single influence, which is fluid ability as it stood during the formative period of crystallized ability, [that] is causative to the present

\footnotetext{
${ }^{52}$ Raymond B. Cattell, “Theory of Fluid and Crystallized Intelligence: A Critical Experiment,” Journal of Educational Psychology 54, 1 (1964):3-4.

${ }^{53}$ For this assessment, see William H. Tucker, The Cattell Controversy: Race, Science, and Ideology (Urbana: University of Illinois Press, 2009), 53-4.

${ }^{54}$ Raymond B. Cattell, “The Measurement of Adult Intelligence,” Psychological Bulletin 40, 3 (March 1943): 1789.
} 
levels of both." ${ }^{55}$ Living, physiologically inflected, and heritable, fluid intelligence describes a threshold of possibility that can be analyzed in the decaying crystallized artifacts of which it is itself a significant cause.

Raymond Cattell was a committed eugenicist. As historian William H. Tucker argues, Cattell shared with mentors Charles Spearman, Cyril Burt, and William McDougall "the belief in the power of heredity as an article of faith necessary for justification of the eugenic agenda, more than as a scientifically demonstrable result. In 1938, discussing the deleterious social effects that would be caused by the disproportionate reproduction of the less intelligent, Cattell declared it an accepted fact that 'mental capacity is largely inborn.'”56 Even if as he would put it in 1964 that "does not mean ... complete hereditary determination,” the fluid capacity animating the crystallized intelligence derived from it is still significantly informed by genetic transfer through sexual reproduction. It flows with the blood.

Jeff Wall is a bookish artist. While the name of Raymond Cattell is largely unknown in the history of art (a field in which Wall pursued postgraduate work at London's Courtauld Institute of Art), the ubiquity of his fluid/crystallized dynamic makes a connection to Wall’s copy-cat binary at least possible. Even without insisting on any direct, historicist linkage, though, the shadow of Cattell's ideas puts Wall’s choice of Milk as framing image for "Photography and Liquid Intelligence” in a new light. Modeled by that lactic fluid prompted in mammalian gestation, Wall's conception of photography as product of wet, immersive, incalculably curvy intelligence meeting dry, projectile rationality plots the medium through a matrix of ancient, humoral theories, casting it in the very sexual-reproductive mold underpinning Cattell's logics. Yet, rather than tarring Wall with Cattell's eugenicist brush by association, the more salient point would be to highlight the fundamental continuity of both with the sexualized, heteronormative terms to which thinking about replication in the arts—including photography itself—is thoroughly addicted. ${ }^{57}$ To extend a view sketched in Julian Stallabrass’s critique, it would be the

\footnotetext{
55 Cattell, "Fluid and Crystallized,” 15.

56 Tucker, 67.

${ }^{57}$ On this theme, see Joel Snyder, “What Happens by Itself in Photography?” in Pursuits of Reason: Essays in Honor of Stanley Cavell, eds. Ted Cohen, Paul Guyer, and Hilary Putnam (Lubbock: Texas Tech University Press,
} 
frictionless cohesion of Wall's liquid intelligence with conservative, institutionalized patterns of thought—along with his pictures' abundant references to canonical art—-that make his work such catnip for art historians and museum taste-makers. ${ }^{58}$

Yet, enthrallment to the terms of liquid intelligence would also be more than but another seduction by what Walter Benn Michaels has called "neoliberal aesthetics."59 Instead, a geometry of curve, line, circle, and slash could fittingly end in a cross: Noah Cross. (Fig. 6: Chinatown) In the Bible, Noah saves terrestrial life as he rises with the waters of the Flood. Noah Cross, Roman Polanski’s infamous Nobodaddy in Chinatown (1974) played by John Huston, controls the flow of water to droughtstarved Los Angeles. Like the maimed, dying Fisher King of Grail legend, Cross is frail; he walks with a cane and reads with bifocals. Jack Nicholson’s would-be knight errant, Jake Gittes, hangs totemic portraits of horses above his bed; chivalric sculptures adorn the shelves in his office where he signs financial contracts to investigate dirty deeds. Cross holds court at the Albacore Club, a massive tuna as its ensign. Gittes trades in bourgeois instruments of credit; he takes checks and follows flows of water as he tries to apprehend what he takes to be Cross's financial motives. Yet, like the fatal puncture of Evelyn Mulwray's eyes at the film's horrific climax, Gittes remains blind to the primeval flow of semen that binds Cross to the daughter he has fathered through another daughter. Paid to recover what he takes to be a missing mistress, Gittes's circulating thoughts of monetary currency unwittingly deliver the grail—not an object, but a bloodline to the future-back to the Fisher King. ${ }^{60}$ By giving ourselves over to the contemplation of liquid intelligence, are we not already plotted into the patsy role of Gittes by forces we can never understand?

Where Nicholson’s Gittes is defaced, this special issues faces squarely up to such baleful

1993), 361-373; Carolina Mangone, “Like Father, Like Son: Bernini’s Filial Imitation of Michelangelo,” Art History 37, 4 (2014): 666-687; and Karin Leonhard, "Vermeer’s Pregnant Women: On Human Generation and Pictorial Representation,” Art History 25, 3 (2002): 293-318.

${ }^{58}$ See Julian Stallabrass, “Museum Photography and Museum Prose,” New Left Review 65 (2010): 93-125.

${ }^{59}$ Walter Benn Michaels, "Neoliberal Aesthetics: Fried, Rancière and the Form of the Photograph," Nonsite.org Issue 1 (Jan. 25, 2011): http://nonsite.org/article/neoliberal-aesthetics-fried-ranciere-and-the-form-ofthe-photograph [accessed November 3, 2016].

${ }^{60} \mathrm{I}$ am indebted to Joel Snyder for this interpretation. 
conclusions. What these essays argue is that liquid intelligence is neither proper to thoughts about Wall nor to photography per se. More to the point, critical engagement with what John Harwood aptly calls “epistemologies of mutability” cannot be condemned in advance at a moment of political danger; instead, their rationalities, logics and intelligences must be drawn rigorously out into the light of day. Wall and his terms are our prompts for opening that inquiry.

The collection begins in medieval China where Jeffrey Moser highlights a development of modern porcelain at the industrial-scale kilns of Jingdezhen that was predicated on systematic elimination of chance from the firing process. Jingdezhen porcelain relied upon the continuity of human agency throughout the firing process to achieve its hallmark aesthetic fine-lined designs under clear glazes on pure, white bodies. To that consolidating episteme of predictive manufacturing, uncontrolled effects— starbursts of ruptured minerals, pendulous gobs of molten glaze, sparking lines of crazed glass—came to be understood under the capacious rubric of yaobian (kiln transformations). Although scantly recorded in the textual record, the material products of this older mindset survive in abundance in the "oil spots" and "hare’s fur” of Jian ware tea bowls, the azure “worm tracks” of Jun ware planters, and the crackles of Guan ware celadons. Moser argues for the value of "liquid intelligence” as an analytical mechanism by which to develop a vocabulary sufficient to represent the complex processes of stimulating serendipity that generated these wares.

Itay Sapir’s contribution moves to the seventeenth-century Italian milieu of Claude Lorrain. Building on the fold that Gilles Deleuze has famously juxtaposed to the seventeenth century's familiar foundationalist aspirations, Sapir argues that a dialectic of liquidity and solidity also serve as productive metaphors for Baroque intelligence and its discontents. Focusing on Lorrain’s port scenes, Sapir argues that the painter depicts the sea as a liquid entity contained in and by a frame of sumptuous, rock-solid architecture, while also subtly subverting the hierarchy of values such compositions might be understood to validate. From painted currents, Jennifer L. Roberts turns to nature-printed paper currency developed in the 1730s by Benjamin Franklin, in collaboration with the botanist Joseph Breintnall. In the decades following their experiments, much of the paper money circulating through the mid-Atlantic colonies 
would feature elegant prints of maple, sage, parsley, blackberry, and other leaves. Because the leaves' delicate and random vein structures could not be engraved by hand, they served as effective anticounterfeiting protection. Roberts argues that liquid intelligence informed these notes at every level: from the veins as natural structures for the movement of moisture through the leaf to the economic "circulation" enabled by paper currency, and on to the liquidities that determine the constitutive acts of printing itself (the casting in liquid metal and plaster needed to mold the leaf matrices to the chanelling of liquid ink). Franklin's notes, Roberts proposes, are revealingly poised on the edge of a fundamental ambiguity within the concept of liquidity as, alternately, an aleatory, material, fluid activity beyond the grasp of rational systems and, on the other hand, a state of controlled and predictable financial convertibility.

Matthew C. Hunter's contribution opens on the opposite side of the Atlantic with the extensive contacts between arbiters of British sea power and Joshua Reynolds, first President of the Royal Academy of Arts and leading society painter. Backed by steady patronage of a West Country elite centered on the port city of Plymouth, Reynolds sailed to Italy and returned to metropolitan artistic triumph in the early 1750s with Captain Augustus Keppel who the painter famously styled as an enlightened Apollo Belvedere. Alongside his slew of Classical postures, however, Reynolds also imported into the heart of Britain's school of painting an appetite for secretive paint formulas, nostrums, and experimental pigments—obsessions that would earn Reynolds the epithet "Sir Sloshua” among Pre-Raphaelite critics in the nineteenth century. Positing between the material epistemologies studied by recent historians of science and a juridico-actuarial framework then emerging to defray risk, Hunter’s essay frames Reynolds's liquid intelligence at the origins of his enterprise as a painter-at the join between his careermaking Keppel and his first picture painted at age twelve on a sail.

Caroline Arscott moves the collection into the nineteenth century as it examines the poetics of the indigo-discharge printing process used by William Morris in the 1870s-1880s. By loading his artifacts with dye upon dye, the indigo discharge process allowed Morris access to what might be called the superabundance of a Pre-Raphaelite relationship to nature. Yet, at the same time, by bleaching he could 
also match the wiped slate or misted glass fundamental to Aestheticist practice with its aloofness to the particularities of nature. Exploring the paradoxical coexistence of dyed fullness and bleached emptiness, Arscott sounds the temporality of the patterning of these indigo discharge fabrics, bearing in mind the context of industrial bleaching linked, as it was, to an acceleration in textile production. Morris's printed textiles thus need to be seen, Arscott proposes, in dialogue with Morris's ambition to make ornament the bearer of primal forces, historical exemplars, class memory and futurity.

John Harwood brings a conversation about liquid intelligence directly into the wheelhouse of modern architectural history. Against heroic narratives whereby modernist architecture freed itself from the shackles of classical form by embracing the structural potentialities of industrial alloys and other new materials, Harwood unearths an occluded genealogy. Metals, by this account, are less the armature of form than the media of communication, binding or (as Harwood shows via engagement with Adam Smith), pinning architectural things together. Tracing metals’ surprisingly belated appearance in architectural theory, Harwood mobilizes an appeal to science fiction found in Wall's essay itself to follow that genealogy of alloys and alliance through the work of Jules Verne. ${ }^{61}$ The special issue concludes with a comment from Sarah Hamill who reflects on its implications as seen from a perspective closer to Wall's photographic practice.

From curve to line, line to circle, the whole diagram slashed out with a Cross: the movement of this collection is recursive. In the end, contra Wall's emphatic planarity, its shape and ethos are better materialized by Oscar Muñoz’s Re/Trato (2004). (Fig. 7: Re/Trato stills) In that twenty-eight minute video projection, a video camera depicts a nervous hand dipping a brush in water to paint a male face on mottled concrete. So hot is the pavement that the brush's wet stain evaporates before the visage can be completed. The task is repeated again and again, changing the schematic imago slightly as the Sisyphean labor unfolds. Like Foucault’s disappearing face drawn on a sandy beach, our inquiry arcs across a

\footnotetext{
${ }^{61}$ For another recent contribution to this journal that has also used Wall's essay to explore works of speculative fiction, see Melody Jue, “Vampire Squid Media” Grey Room 57 (2014): 82-105.
} 
protracted early modernity. It traces as much the visible logics of fluids as the invisible relations that now make us and now bind us; but, from them, we too might be free. 